\title{
HIV scandal sinks Chilean health minister
}

$\mathrm{C}$ hilean authorities are overhauling the country's HIV/AIDS programs after more than 500 patients who tested positive for the virus were not informed of the results.

The controversy has also resulted in the resignation of the country's health minister, Maria Soledad Barria, as well as legal proceedings against 20 health care staff in northern Chile.

The scandal began last July following the death of Dearnny Aguilar, a young mother who had tested positive for HIV in 2004, but was never notified.

Her death prompted Iquique Regional Hospital, in Iquique, Chile, to conduct an investigation into HIV test records, which showed that approximately 2 dozen other HIV-positive patients had not received their test results. Hospital officials reported that 3 of those patients had died, 8 others were receiving treatment, 2 had left the country, 2 had been retested and found to be HIV-negative, while 9 could not be located. A subsequent countrywide investigation revealed that at least 512 people had not been informed that they were carrying the virus, including several blood bank donors in Santiago.

The case has embarrassed the government of President Michelle Bachelet, a former pediatrician and epidemiologist. Following Aguilar's death, Barria held a press conference to announce a series of corrective measures, including the resignation of Iquique's health services director and improvements in hospital HIV/AIDS procedures.

As the number of cases of patients left in the dark about their HIV-positive status rose, some members of Chile's congress called for Barria's impeachment. She resigned in early November 2008. An investigation by the National Comptroller's Office found severe irregularities in HIV/AIDS procedures at the Iquique hospital, including the use of expired HIV testing kits on 89 pregnant women and altering of testing machinery to prevent it from rejecting expired kits. Among those facing charges are the hospital's director, the regional health ministry official, a former National AIDS Commission officer, 5 doctors and 7 blood bank specialists.

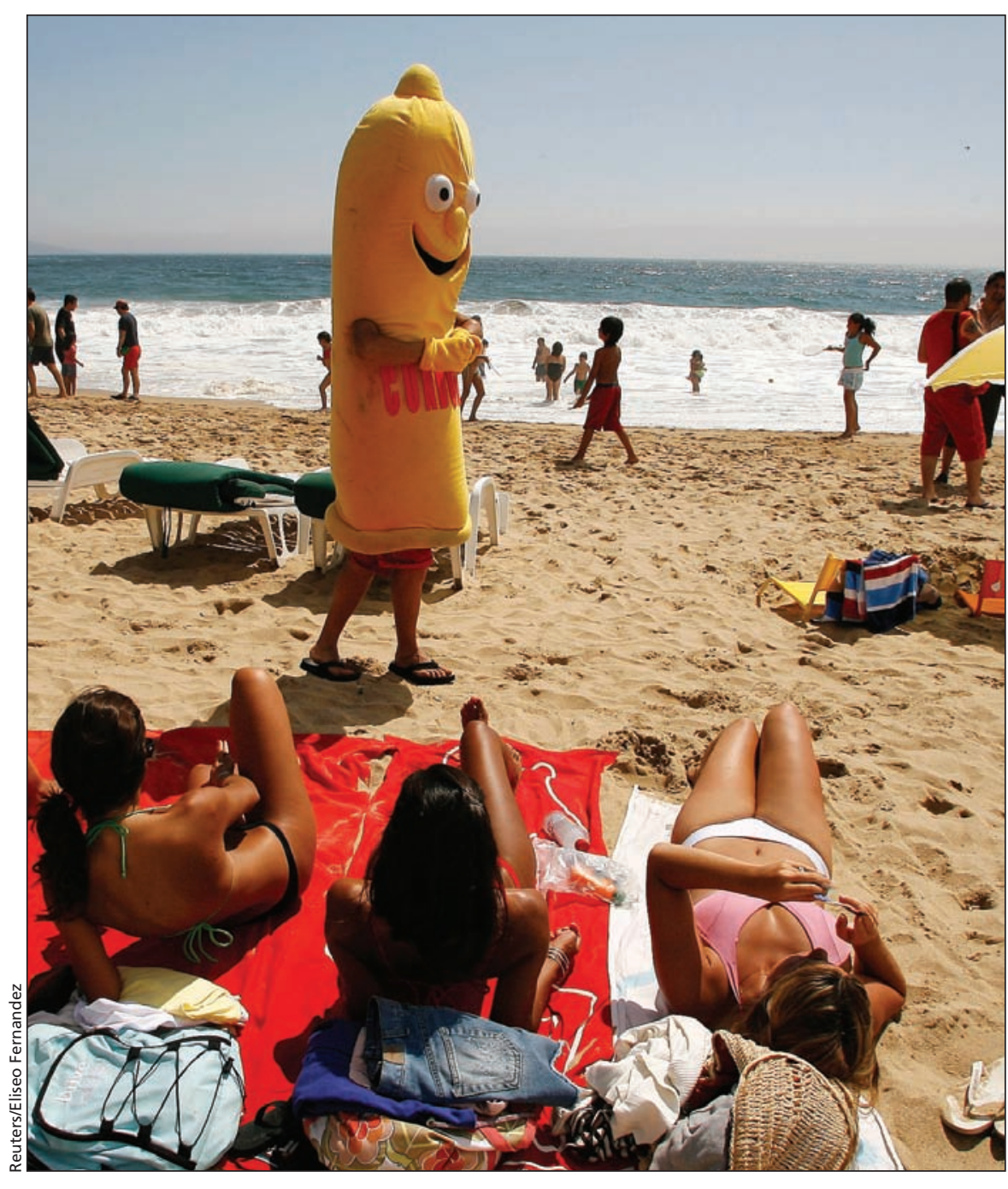

A man dressed in a condom costume hands out contraceptive sheaths at Vina del Mar, Chile, as part of a campaign by the Chilean Corporation for the Prevention of AIDS.

Chile's new health minister, Alvaro Erazo, announced a unified HIV/AIDS registry system for the public and private health systems late last year, while presenting a report to the Chilean congress's health commission which stated that of the 6636 people who had tested positive for HIV/AIDS between 2004 and August 2008, 81.3\% had received their results. Of the 512 patients not notified, health officials tracked down 244 "through telephone calls, home visits or certified letters," according to Erazo. Health officials said 58 patients had given false addresses or contact details at the time of testing.

In early February, Chilean authorities uncovered another 104 patients us- ing private health care facilities between 2004 and 2008 who had tested positive for HIV without being informed.

Marco Becerra, national coordinator for ASOSIDA, an umbrella organization of HIV/AIDS groups, told CMAJ that while HIV/AIDS patients are guaranteed free or low-cost treatment, there is no consensus on public education and methods of prevention, "even though preventing the disease is much cheaper than treating it."

In contrast, Brazil has one of the biggest condom distribution programs in the world. - Mary Helen Spooner, London, England

DOI: $10.1503 / \mathrm{cmaj} .090128$ 